Benha Veterinary Medical Journal 40 (2021) 53-55

Benha Veterinary Medical Journal
$\begin{gathered}\text { Officil Jounnal Issued by } \\ \text { Faculty of } \\ \text { Veterinary Medicine }\end{gathered}$
Original Paper

\title{
Chemical evaluation of imported fish
}

Saad, M.S. ${ }^{1}$, Islam, Z. ${ }^{2}$, Islam, I.S. ${ }^{1}$, Ibrahim, I.A ${ }^{\mathbf{1}}$.

${ }^{1}$ Food Hygiene and Control Department, Faculty of Veterinary Medicine, Benha University, Egypt.

${ }^{2}$ Bacteriology Department, Animal Health Research Institute. Doki, Giza.,

\section{ARTICLE INFO}

Keywords
TVN
TBA
Canned fish

Received 23/03/2021

Accepted 31/03/2021

Available On-Line

$01 / 07 / 2021$

\begin{abstract}
Canned fish portions had laid down limits of $\mathrm{pH}$ that should not be more than 6.7; TVN should not be more than $40 \mathrm{mg} / 100 \mathrm{~g}$ (EOS, 2005). This study was conducted on 105 samples of imported canned fish for recording the chemical evaluation of these samples. The chemical examination declared that the mean values of TBA and TVN were $14.8 \pm 1.4$ and $23 \pm 1.5 \mathrm{mg} \%$ for canned mackerel, $\quad 4.8 \pm 0.4$ and $23.2 \pm 0.6 \mathrm{mg} \%$ for canned sardine and $1.9 \pm 0.1$ and $18.6 \pm 2.5 \mathrm{mg} \%$ for canned tuna, respectively. Significant differences $(\mathrm{P} \geq 0.05)$ appeared between the examined samples of canned mackerel, sardine and tuna as a result of TBA and TVN values. current study classified the presence of some unacceptable imported canned fish for human consumption that indicate the importance of chemical evaluation of canned fish. recommended future study must be applied chemical and molecular methods to compare efficiency of current chemical method to control this problems in future and save people health
\end{abstract}

\section{INTRODUCTION}

Fish species found in different analyzed brands were sardine, tuna and mackerel are good source of high protein, fat, minerals and omega-3, unsaturated fat ,which fit for infants and adults (Odiko and Obirenfoju, 2017).The comparatively high phospholipids content cause the rise of TBA numbers found normally in lean tissues, through, TBA test has the advantage that it apparently measures the deteriorations in both extractable and non extractable lipids (Pearson,1968). the collaborative study concerning TVN and concluded that the TVN method is routine method which should only be used to determine whether the fish is fit or unfit for human consumption and suitable for identification of early stage of freshness (Antonacopoulos and Vyncke ,1989). The TVN could be considered as a good index of freshness, spoilage degree and shelf life of cold and frozen storage fishes, they also used the TMA as an objective quality indicator in some fish such as Cod and Haddock (Wong and Gill , 1987).

The method for testing the objective rancidity development in fish based on thiobarbituric acid substances (Robles Martinzet al., 1982). The last statistics of the total world fishery production was 167.2 million tones. around $87.5 \%$ of this production for human consumption, and canned fish represented about $13.0 \%$ (19 million tons) of this ratio(FAO,2014). canned fish portions had laid down organoleptic examination for the quality of imported canned fish was evaluated for their color, odor, taste and consistency by panel of five judges ranging from 5 to 1 (Ogubanwo and Okanlawon,2006).

\footnotetext{
* Corresponding author: ebrahim.mussa15@fvtm.bu.edu.eg
}

limits of $\mathrm{pH}$ that should not be more than 6.7; TVN should not be more than $40 \mathrm{mg} / 100 \mathrm{~g}$ ( egyptian Organization for Standardization EOS , 2005). The Egyptian researchers tried to produce canned products from crayfish (procambarus clarkii) flesh. The outcomes from this investigation showed that crayfish flesh was rich in protein and fat contents. TVN. tri methylamine, TBA, $\mathrm{pH}$ values and total bacterial count ensured that crayfish flesh had high quality and was safe for human consumption (EL-Sherif and Abd El-ghafour,2015). study was conducted on 105 samples of imported canned fish for recording the chemical evaluation (TBA-TVN) of these samples.

\section{MATERIAL AND METHODS:}

Collecting of samples:

A total of 105 random samples of imported canned mackerel, sardine and tuna (35 of each) were collected from different markets at Qalyobia governorate for determination of their organoleptic and chemical, all collected samples of canned fishes were subjected to the following.

Organoleptic examination:

$\begin{array}{lllc}\text { samples } & \text { mackerel } & \text { sardine } & \text { tuna } \\ \text { score } & 3 & 4 & 5\end{array}$


Organoleptic examination for the quality of imported canned fish was evaluated for their color, odor , taste and consistency by panel of five judges ranging from 5 to 1 (Ogubanwo and Okanlawon 2006). Results recorded according to following parameters

\begin{tabular}{c|l}
\hline (5 score) & High acceptable ( pale pink color - fresh fleshy odor-firm and tender in consistency) \\
\hline (4 score) & Acceptable (slight pink color- fleshy odor-firm in consistency) \\
$(3$ score $)$ & Moderately acceptable (pale red color- fleshy odor-slightly firm in consistency) \\
\hline (2 score) & $\begin{array}{l}\text { Border line (slightly pale red color-slightly fresh odor-slightly soft in consistency } \\
\text { Rejected abnormal sample (grayish red color-rancid odor- softness and slimness in } \\
\text { consistency) }\end{array}$ \\
\hline
\end{tabular}

\section{1.Chemical examination:}

2.1.1: Determination of Total Volatile Nitrogen (TVN): The technique applied for determination of TVN was recommended by Food Agriculture Organization "FAO" (1980). $25 \mathrm{~g}$ of the fish sample, $75 \mathrm{ml}$ of distilled water were added and thoroughly mixed by a blender for 2 minutes and 2 drops of Molecular Hydrochloric Acid (MHCL) (1\%) were added to bring $\mathrm{pH}$ value to 5.2. The homogenate was heated to $70^{\circ} \mathrm{C}$ and then cooled to room temperature and filtered. Accurately, $2 \mathrm{ml}$ of $0.01 \mathrm{MHCL}$ were added into the inner ring of the Conway dish. While, the outer ring was filled with $2 \mathrm{ml}$ of the extract and $1 \mathrm{ml}$ of saturated potassium carbonate. The Conway unit was rotated as gently as possible. The dish was covered and incubated at $36^{\circ} \mathrm{C}$ for 2 hours. However, HCL was titrated against $0.01 \mathrm{M} \mathrm{NaOH}$ by using methyl red indicator $\left(\mathrm{T}_{1} \mathrm{ml}\right.$, final dilution of $1 / 10 . \mathrm{TVN}=26.88$ $\mathrm{X}\left(2-\mathrm{T}_{1}\right) \mathrm{mg} / 100 \mathrm{~g}$ fish Where, $\mathrm{T}_{1}=$ volume of $\mathrm{NaOH}$ consumed in the titration.

2.1.2.Determination of Thiobarbituric Acid Number "TBA" (Vyncke, 1970):

In a clean blender, $20 \mathrm{~g}$ of fish sample were blended with $100 \mathrm{ml}$ of $7.5 \%$ trichloroacetic acid solution for 2 minutes. The homogenate was then filtered $5 \mathrm{ml}$ of TBA reagent $(0.02 \mathrm{M})$ were added to accurately $5 \mathrm{ml}$ of the filtrate in a test tube with screw cap. The tube was placed in a water bath for 40 minutes. The absorbance of the resulting color was measured by using spectrophotometer (Spectronic 21, Bye model, Germany) at wave length
$538 \mathrm{~nm}$. The TBA values were recorded as $\mathrm{mg}$ malonaldehyde per $100 \mathrm{~g}$ fish.

Calculation:

$$
\begin{aligned}
& \text { Concentration of malonaldehyde } \\
& =\frac{0.016+2.782}{10}-\mathrm{Xmg} / \mathrm{lo} 0 \mathrm{~g}
\end{aligned}
$$

Where, $\mathrm{X}=$ the absorbance

\section{RESULTS:}

Results achieved in Table (1) showed that the Thiobarbituric acid number (TBA) in examined samples of canned fish ranged from 1.3 to 29 with an average of $14.8 \pm 1.4 \mathrm{mg} \%$ for canned mackerel, 0.6 to 9.4 with an average of $4.8 \pm 0.4 \mathrm{mg} \%$ for canned sardine and 1.1 to 2.9 with an average of $1.9 \pm 0.1 \mathrm{mg} \%$ for canned tuna.

Table (2) indicated that the differences between the examined samples of various canned fishes based on their TBA values were significant $(\mathrm{P} \geq 0.05)$. It is evident from the results recorded in Table (3) that the Total Volatile Nitrogen (TVN) in examined samples of canned fishes ranges from 11 to 43.7 with an average of $23 \pm 1.5 \mathrm{mg} \%$ for canned mackerel, 8.4 to 28 with an average of 23.2 $\pm 0.6 \mathrm{mg} \%$ for canned sardine and 5.3 to 53.4 with an average of $18.6 \pm 2.5 \mathrm{mg} \%$ for canned tuna. Significant differences $(\mathrm{P} \geq 0.05)$ were appeared between the examined samples of various canned fishes with respect to their TVN as shown in Table (4). EOS, (2005) reported that TVN should not be more than $40 \mathrm{mg} / 100 \mathrm{~g}$.

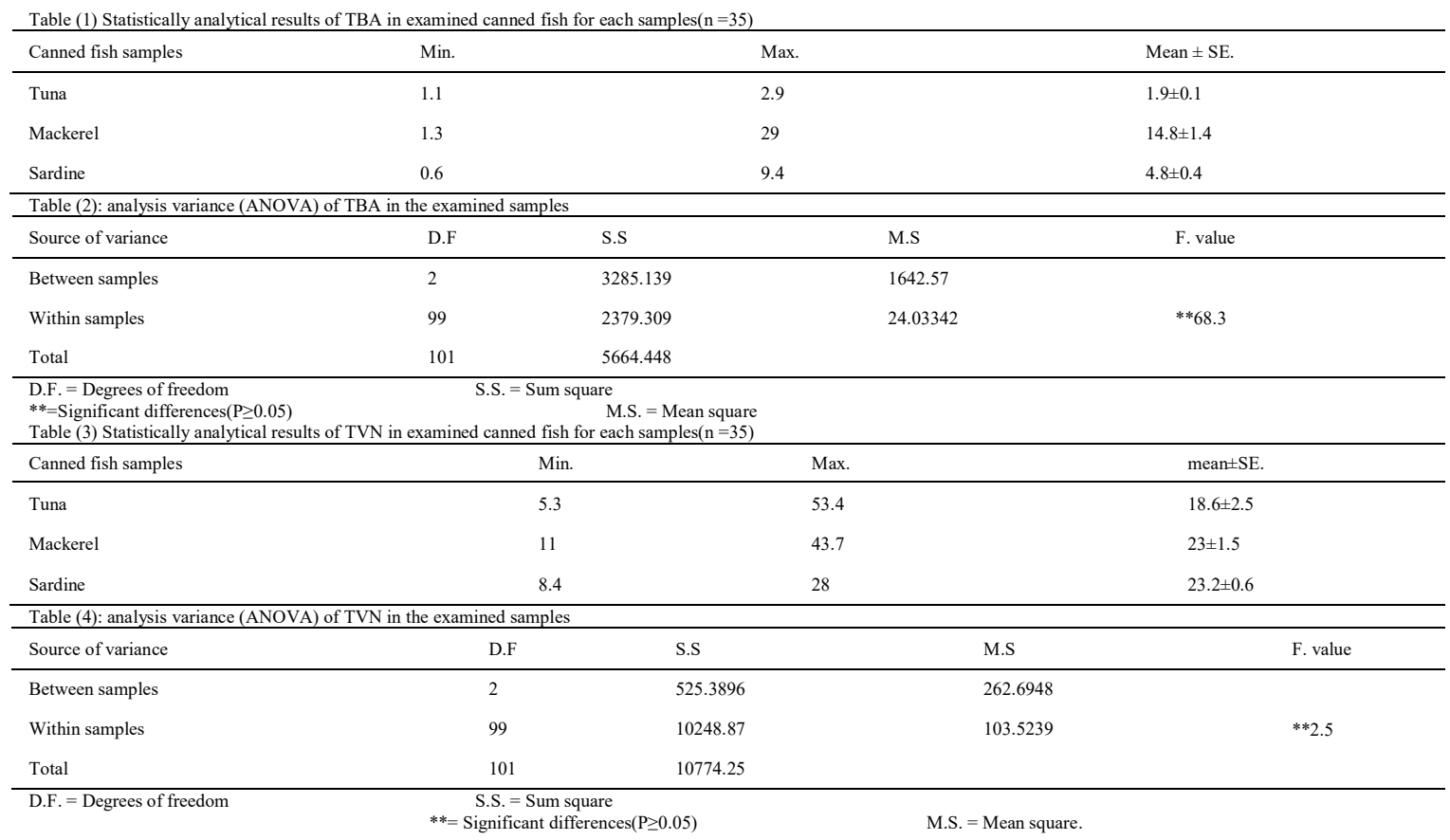




\section{DISCUSSION}

The method for testing the objective rancidity development in fish based on thiobarbituric acid substances (Robles Martinzet al ,1982). Table (1) indicate that the Thiobarbituric acid number (TBA) in examined samples of canned fish ranged from 1.3 to 29 with an average of $14.8 \pm 1.4 \mathrm{mg} \%$ for canned mackerel, 0.6 to 9.4 with an average of $4.8 \pm 0.4 \mathrm{mg} \%$ for canned sardine and 1.1 to 2.9 with an average of $1.9 \pm 0.1 \mathrm{mg} \%$ for canned tuna.

Table (2) showed the differences between the examined samples of various canned fishes based on their TBA values were significant $(\mathrm{P} \geq 0.05)$. The obtained lower results were obtained by (Mahmoud, 1994). Moreover, TBA value increases during freezing storage period and reach the level of 0.24 and $0.29 \mathrm{mg} / 1000 \mathrm{~g} \mathrm{~T}$. nilotica after 6thmonth of storage (Mahmoud,1994). The spoilage bacteria have the ability to decompose not only protein and other nitrogenous substance but also fat (Love, 1980). Table (3) detect that the Total Volatile Nitrogen (TVN) in examined samples of canned fishes ranges from 11 to 43.7 with an average of $23 \pm 1.5 \mathrm{mg} \%$ for canned mackerel, 8.4 to 28 with an average of $23.2 \pm 0.6 \mathrm{mg} \%$ for canned sardine and 5.3 to 53.4 with an average of $18.6 \pm 2.5 \mathrm{mg} \%$ for canned tuna. Significant differences $(\mathrm{P} \geq 0.05)$ were appeared between the examined samples of various canned fishes with respect to their TVN as shown in Table (4). EOS (2005) reported that TVN should not be more than $40 \mathrm{mg} / 100 \mathrm{~g}$. The TVN could be considered as a good index of freshness, spoilage degree and shelf life of cold and frozen storage fishes, they also used the TMA as an objective quality indicator in some fish such as Cod and Haddock (Wong and Gill ,1987).

\section{REFERENCES:}

1. AntonacopouLos, N., Vyncke, W. 1989. Determination of volatile basic nitrogen in fish: a third collaborative study by the West, European Fish. Technologists Association (WEFTA).Z. Lebensm Unters Forsch.189-197.
2. Cobb, B.F., Vanderzant, C. 1971. Biochemical change in Shrimp inoculated pseudomonas,bacillus coryneform bacterium. J. Milk Food Tech., 34:533 - 540. 3. Egyptian Standard Specifications (ES) 2005. No. 1651 for chilled raw poultry and rabbit meat, No. 3492 for chicken frankfurter, and No. 3493 for heat treated poultry meat products.

4. EL-Sherif, Abd El-ghafour, 2015. nutritive value of canned river nile cray fish products EGYPT .J.Aquat.Res.41,265-27.

5. Food and Agriculture Organization (FAO) 1980. Manual of Food Quality Control, 4. Microbiological Analysis.FAO, United Nations, Rome, Italy.

6. (FAO) Food and Agriculture Organization 2014. Fisheries department statistical databases and software,year books of fishery statistics summary tables (DEC.2018).

7. Love, R.M. 1980. The chemical biology of fishes. Academic Press, Vol.2, London.

8. Mahmoud, Y.E. 1994. Studied on Frozen Fish. Ph. D. Thesis, Fae.Vet. Med., Moshtohor, Zagazig Univ., Benha Branch.

9. Odiko, Obirenfoju, J. 2017. proximate composition and mineral contents of diffferents brands of cannned fishes marketed in Edo state Nigeria. Int. J. Fisher. Aquacult .Res.3 (2),30-38.

10. Ogubanwo , Okanlawon, 2006. Microbial and Sensory Changes During the Cold Storage of Chicken Meat Treated with Bacteriocin from L. brevis OG1 Pakistan Journal of Nutrition. 5, 601-605

11. Martinz, R.C., Carrants, E., Ke, P.T.M. 1982. Recommended in fish based on TBA (thiobarbituric acid reducing substances) formation. Canada, Technical Report of Fisheries and Aquatic Science, 1089:27.

12. Vyncke, W. 1970. Direct determination of the thiobarbituric acid value in trichloroacetic acid extracts of fish as a measure of oxidative rancidity. FetteSeifenAstrichmittel 2:1084-097.

13. Wong, K., Gill, T.A. 1987. Enzymatic determination of trimenthylamine and its relationship to fish quality. J. Food Sci. 52:1. 